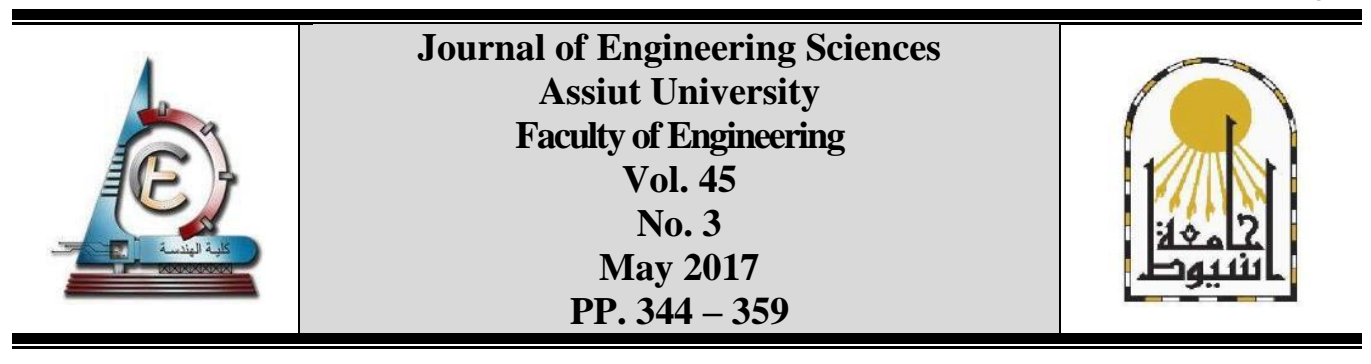

\title{
INVESTIGATING THE THERMAL COMFORT CONDITIONS IN AN EXISTING SCHOOL BUILDING IN EGYPT
}

\author{
Hala Hammad, Morad Abdelkader, Ahmed Atef Faggal \\ Depart. of Architecture, Faculty of Engineering, Ain-Shams University Cairo, Egypt
}

Received 30 November 2016; Accepted 10 January 2017

\begin{abstract}
This paper investigates, using software modeling and numerical simulations, the annual thermal performance of a public primary school in Cairo governorate in Egypt. This investigation identifies how much time the students achieve thermal comfort in their classrooms during the whole academic year. It is also considered as an attempt to magnify the need for solutions that can enhance thermal comfort in classrooms. As a support to our computer modeling and simulation, this paper preforms also an analysis to the thermal comfort indices via field measurements for the internal temperatures and humidity of a classroom by using the Elitech UR4HC temperature-humidity data logger. The field measurements have taken place in June 2016 for a whole school day from 8:30 am until 14:30 pm. Energy Plus simulation tool has been used utilizing its modeling interface Design Builder. The numerical simulation proposed has considered the real construction aspects and parameters of the classroom case study. Measurements validate the simulation results and ensure that the tool is reliable to be used in the annual simulations, which is the main concern of this paper.

This paper presents, through annual building thermal-performance simulations, the forecasting for the yearly mean indoor air temperatures, Predicted Mean Vote (PMV) model, discomfort hours, and internal heat gain balance. Simulation results indicate the existence of a high level of thermal discomfort during the whole academic year. The annual analysis also indicates around $45 \%$ of the working hours are exceeding the maximum limit of the comfort temperature range. Furthermore, the results present a high level of average annual internal heat gain balance throughout the academic year.

As a main contribution of this paper, the simulation results draw attention to the importance of integrating new passive cooling strategies or energy efficient cooling systems in order to: stabilize the indoor temperature, increase the students' thermal comfort and decrease the internal heat balance for enhancing the thermal performance of school buildings in the future.
\end{abstract}

Keywords: thermal comfort, discomfort hours, Predictive Mean Vote (PMV), overheating hours, internal heat gain, cooling load

\section{Introduction}

Educational buildings are one of building types necessarily of great interest when one consider the potential links between building performance, thermal comfort, and energy consumption [1]. The reason is that the students spend long times in their classrooms, thereby, a good indoor environment can help in optimizing conditions for students' performance. Classrooms thermal performance not only affects the students' health and 
comfort, but also it affects the students' learning efficiency and productivity [3]. Recently, most of new school buildings have been constructed without considering students' thermal comfort. Many researches show that as temperature increases above $26^{\circ} \mathrm{C}$, students' performance decreases significantly [3, 4 and 5].

According to literature, indoor thermal comfort has been widely investigated for different types of public spaces. For educational halls, there are a considerable amount of publications that have been considering the college students' thermal comfort and lecture halls thermal performance. A. Abdallah (2015) analyzed the indoor thermal comfort and energy consumption inside a large educational hall at the Faculty of Engineering, Assiut University; the research was aiming at determining the acceptable operating temperature for students' comfort [3]. His results show that the indoor temperature exceeds $28^{\circ} \mathrm{C}$ in summer months and is far from the $90 \%$ acceptable comfort range with a high PMV range. K. M. Dewidar et al. (2013) monitored the indoor temperature inside a large lecture hall in Cairo University; they conducted measurements for temperature, relative humidity, and wind speed for 30 points inside the hall [9]. They concluded a high level of thermal discomfort and suggested to operate passive systems that could control temperature, relative humidity and solar radiation. However, they do not compare their results with the thermal comfort index and they do not consider the thermal sensation scale. Furthermore, Farghal (2011) set an Adaptive Comfort limit for university buildings in Cairo through a subjective field study of occupants in educational halls in three Universities in Cairo [12].

On the other hand, only few studies in the literature investigate the thermal comfort criteria within school buildings in Egypt. In this context, Gado and Mohammed (2009) investigate the thermal comfort criteria from the subjective view of occupants and through measurements of temperatures during May month. This has been carried out inside primary governmental schools in AL-Minya governorate in Egypt [10], [11] and [13]. Their Results indicate that internal air temperatures of all the case studies exceeded the comfort temperature for most of the time and average PMV across the case studies was 1.7 which indicates that the majority of the occupants would feel unpleasantly warm. In addition, A.A. Saleem et al. (2014) examined the thermal performance of a public primary school in Assiut city, Upper Egypt [14]. Their findings indicate a high level of thermal discomfort. The average measured values of both the PMV and PPD inside the classrooms were 1.17 and $38.86 \%$ respectively. Moreover, it indicates that there are a strong relation between indoor comfort conditions and outdoor temperature.

It is clear from the literature review, and up to the knowledge of the authors, that all researches investigate the students' thermal comfort for a maximum duration of one month and do not consider the annual thermal performance analysis. Hence, there is not any research that investigates the thermal performance of school buildings in Cairo for a complete year of investigation. Therefor this paper comes to fill in this gap and investigates, through numerical simulations and computer modeling, the annual thermal performance of a governmental primary school building in Cairo governorate. The results of this paper monitor the thermal comfort criteria and internal heat balance, during a complete academic year, in order to draw the attention to the need for cooling systems that can be integrated to future school buildings to achieve thermal comfort.

In order to briefly summarize the structure and analysis of this paper, it is important to highlight the problem definition of this research and its main objectives: 
Problem definition: indoor-spaces in school buildings have been rarely studied for a complete yearly thermal performance compared to other buildings, e.g., offices and residential buildings.

Main objectives: The main objective of this paper is to evaluate the annual thermal performance of a classroom as a base case to all classrooms in order to monitor the thermal comfort criteria, number of discomfort hours, and internal heat balance throughout a whole academic year. This is done to be able to develop more energy efficient systems and sustainable design guidelines for future school buildings in Cairo.

This paper is organized as follows: Section 1 is this introduction. Section 2 concerns monitoring and simulating the thermal comfort indices of an existing governmental school building in Cairo in a perfect summer day. Moreover, it estimates the space thermal performance throughout an academic year through annual simulations. Section 3 analyzes the annual simulation results by evaluating the mean indoor air temperature, the predictive mean vote model, the number of discomfort hours and the internal heat balance. Finally, Section 4 is the conclusion of this work and recommendation for future work.

\section{Methodology}

\subsection{Case study monitoring}

This research studies the human thermal comfort criteria inside Taba public primary school in Cairo, Egypt. The school building is consisting of 32 classes, it was built in 2001. Field measurements took place during June 2016, in a single selected classroom. Fig. 1a presents the northern elevation while Fig. $1 \mathrm{~b}$ presents the southern elevation of the school building.

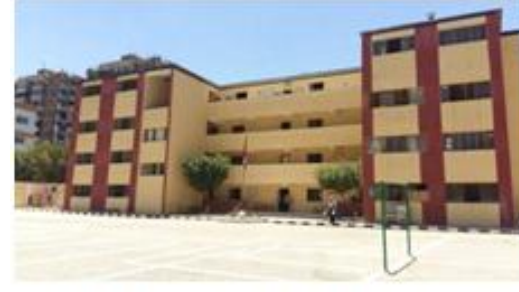

Fig. 1. a. Taba school northem elevation

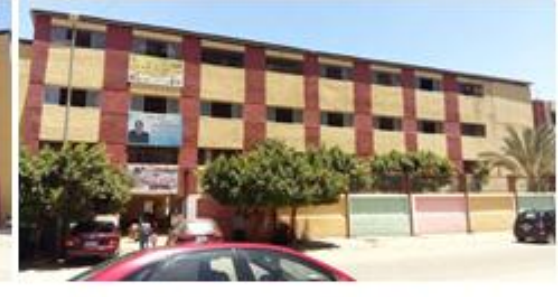

Fig. 1. b. Taba school southem elevation

Taba Public School (now its name is changed to: the Martyr Colonel Hisham Al-Deen Abd Al-Aziz School) is located in Nasr city, on Makram Ebaid Street. The coordinates of the school is exactly $30.0276^{\circ} \mathrm{N}$ and, $31.2101^{\circ} \mathrm{E}$, as depicted in the Google map and satellite capturing in Fig. 2. The site is surrounded by medium rise residential buildings. Its total area is about $450 \mathrm{~m}^{2}$, consists of four stories each story is $2.90 \mathrm{~m}$ height. The building represents a single sided Ushape form prototype of public school buildings; see Fig. 3 for more details about the floor plan.

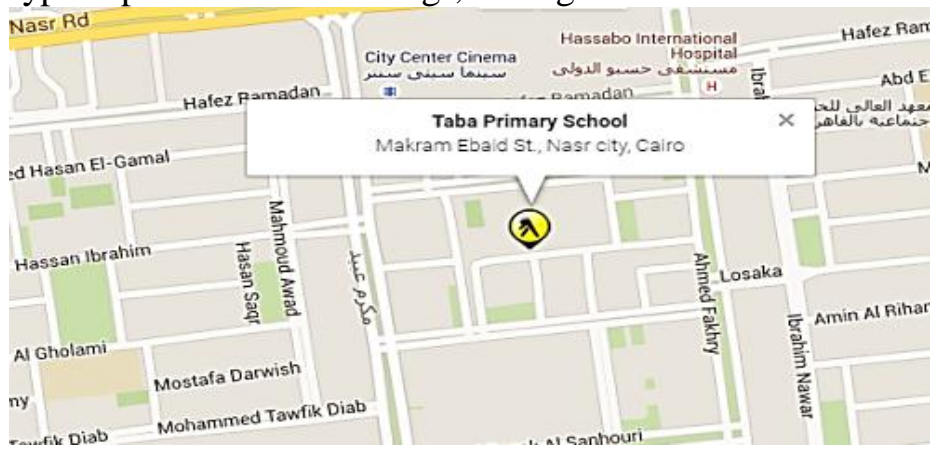

Fig. 2. Taba primary school site location in Nasr city region in Cairo 
Hala Hammad et al., Investigating the thermal comfort conditions in an existing school building......

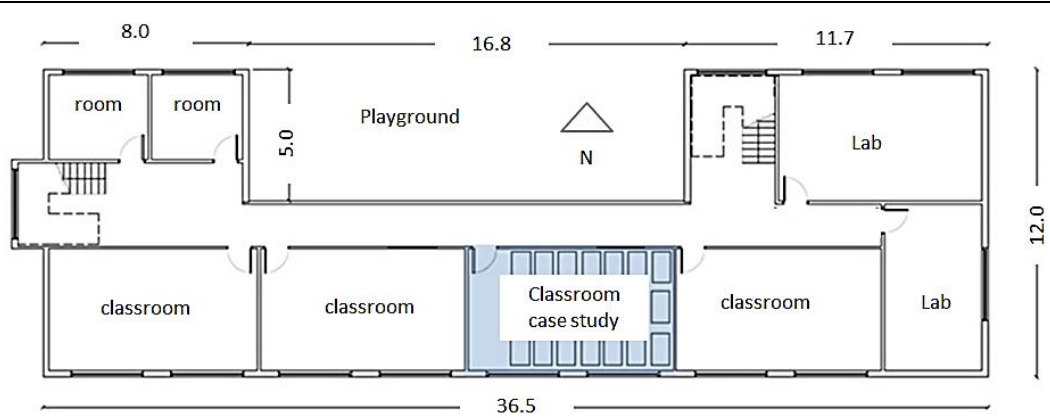

Fig. 3. Typical floor plan of Taba governmental primary school and the selected reference case classroom

The classroom under investigations is located in the second floor with a total flat area of $38.4 \mathrm{~m}^{2}$. The classroom contains three glass/sectional-aluminum windows, each is $2.8 \mathrm{mx} 1.3 \mathrm{~m}$. Two of these windows are pointing to the south and one to the north. The room is furnished with 3 rows of seats/desks; each row contains 7 seats/desks, i.e., a total number of 21 seats/desks. Every wooden seat/desk carries 2 students; thus, the total number of students is 42 students. Additionally, it contains one more wooden desk/chair for the teachers; see Fig. 4 for more insights about the classroom internal furniture. The room has internal dimensions of $8 \mathrm{~m} \times 4.8 \mathrm{~m} \times 2.9 \mathrm{~m}$ (length $\times$ width $\times$ height). It contains one external wall facing south. The northern wall is overlooking on an outdoor corridor facing the north orientation, the ceiling and the floor are not directly exposed to the outdoor environment.

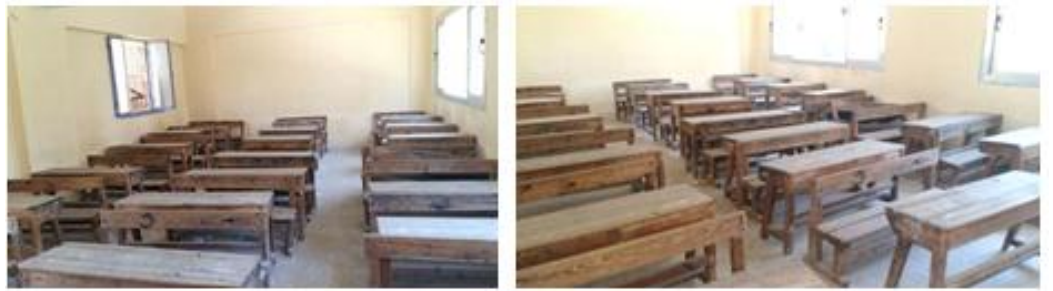

Fig. 4. Classroom interior views

The school construction is monitored as conventional construction building materials. The external walls are of most common wall systems which consist of $25 \mathrm{~cm}$ brick with plaster finishing. The floor construction consists of $15 \mathrm{~cm}$ reinforced concrete finished with mixture-marble tiles, and the internal partitions consist of $12 \mathrm{~cm}$ brick with a $2 \mathrm{~cm}$ plaster coating. As mentioned before, the south façade has two windows each of $2.80 \mathrm{~m} \times 1.30 \mathrm{~m}$ (length $\times$ height), while the northern façade has one window of $2.80 \mathrm{~m} \times 1.30 \mathrm{~m}$ (length $\times$ height) of single glazing with no shading devices and it is naturally ventilated with no fans.

\subsection{Measurements and data recording}

The equipment used for measuring and recording the classroom indoor temperatures and humidity is the Elitech tempreture-humidity data logger (model URC-4HC) [16]. The spot of measurements was on the student's middle desk at a height of $65 \mathrm{~cm}$ from the ground, as shown in Fig.5. The actual measurements take place every 1-minute intervals the measurements are though averaged and saved every 10 minutes. Also, the data logger was carefully placed to avoid any unnecessary impact, such as direct sunlight. Measurements took place on the $22^{\text {nd }}$ of June, as it has been selected as a typical summer day which represents extreme hot conditions. Measurements have taken place from 8:30am until 2:30pm every 10 minutes. 


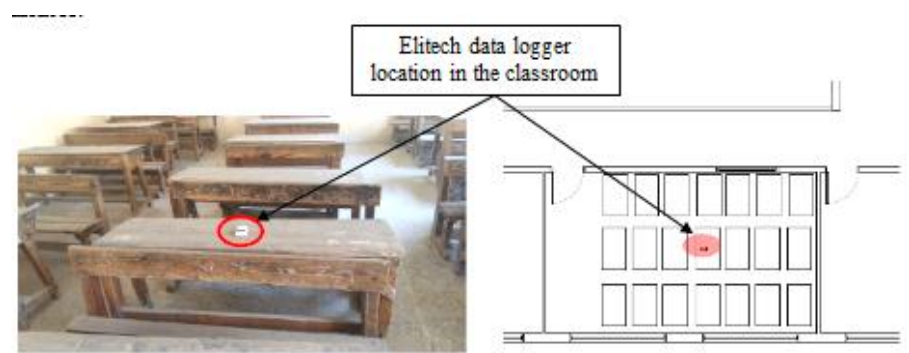

Fig. 5. Position of the data logger on the desk in the middle of the room

For the outdoor measurements we use an identical device similar to the one used for the indoor. An outdoor sensor was connected to the device from the nearest window in the classroom at the second floor level. The measurement values are presented in the next section, where a relationship between the indoor conditions and the occupants' thermal comfort is demonstrated. It is worth to mention that during this measurements day, the students' capacity was about $30 \%$ of the normal capacity in the classroom due to low capacity of summer courses in June.

\subsubsection{Air temperature}

As stated before, the air temperatures and humidity, during the time interval from 8:30am until 2:30pm in the selected classroom, is averaged every 10 minutes; the outdoor temperature is measured with the same manner. Figure 6 presents a comparison between the indoor and outdoor temperature variations monitored throughout the whole school day hours mentioned before.

The measured values clearly show that the temperatures inside the classroom, during this day, are ranging from $27.5^{\circ} \mathrm{C}$ at the early morning, about $31^{\circ} \mathrm{C}$ during that daytime, and a maximum of $33.5^{\circ} \mathrm{C}$ at the end of the school day. However, the Adaptive Comfort Standard (ACS) (based on [6]) in this case is calculated to be in the range of $23.5-28^{\circ} \mathrm{C}$, which is less than the actual measurements.

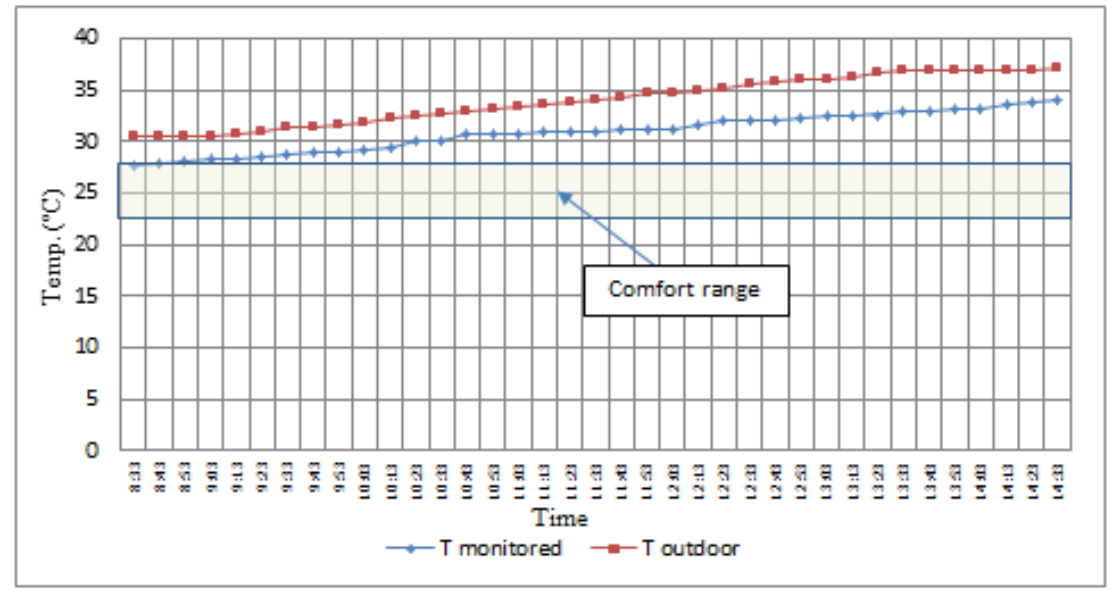

Fig. 6. indoor and outdoor air temperature inside the classroom throughout the whole school day

Thus, the measurements reveal that the mean indoor air temperature is raised by about $6^{\circ} \mathrm{C}$ on average. This level of increase can lead to thermal discomfort conditions for students. As referred to [6], one can see that the temperature level in this case is higher than the range of human thermal comfort; though, the temperature on the early morning (from 8:30am until 10:13am) was near to the comfort range. Moreover, the finding in Fig. 6 tells that there is a strong relation between the indoor temperature variations with the 
indoor one, where the difference between the outdoor and indoor temperature are almost constant, i.e., about $4^{\circ} \mathrm{C}$, until the end of the school day. This mandates the urgent need for finding solutions for improving the space thermal behavior.

\subsubsection{Relative humidity}

Relative humidity measurements, recorded in Fig. 7, shows that the level of variation within the classrooms is fluctuated between $34 \%$ and $56 \%$ over the monitored school hours with a mean percentage of about $46.1 \%$. In addition, the relative humidity was, on average, about $50 \%$ until $12: 00 \mathrm{pm}$, and then it decreases slightly to reach $34 \%$ at the end of the school day.

Honestly speaking, the measured values are affected by a main reason which is this: the measurement day is during the summer school courses period, i.e., is until 12:30pm and is not a normal full capacity studying day (the students' capacity in the classroom was about $30 \%$ of the normal full capacity). Thus, the measurements still indicate that the relative humidity is still in thermal comfort range, according to SHRAE (35- 60\%) [6], it is expected that these values are subjected to be increased if the classroom was of full school day with full capacity.

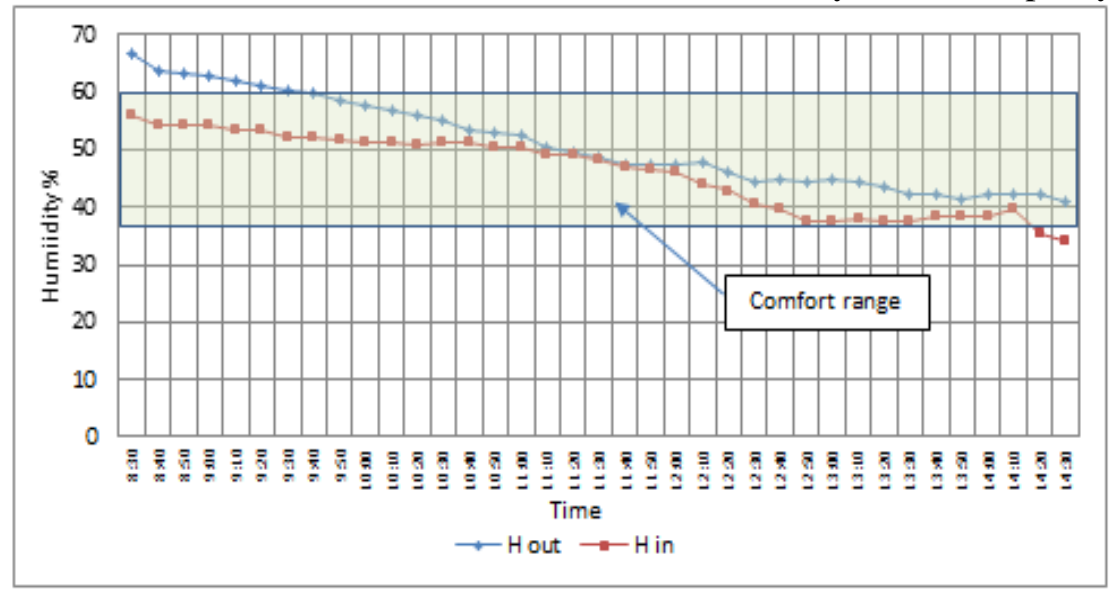

Fig. 7. Relative humidity inside and outside the classroom base case

\subsection{Modeling and simulation}

The author has selected the simulation tool Energy Plus (E+), version 8.2.0.024, with an interface to the software modeling tool Design Builder (DB), version 4.2 [17]. The simulation tool $\mathrm{E}+$ has been selected since it is widely used in the scientific communities as a tool for thermal and energy performance simulations. Additionally, it has been considered to be more suitable for making realistic simulation models using very realistic architectural models and facilitates the use of Energy Plus. The latter has been validated under the comparative Standard Method of Test for the Evaluation of Building Energy Analysis Computer Programs BESTEST/ASHARE STD [18]. In addition, it has been validated by Energy Efficiency and Renewable Energy (EERE) program, U.S. Department of Energy (DOE). Moreover, Wael Sheta et al. (2010) have validated the Design Builder modeling tool (using Energy Plus simulation environment) in Egypt, specifically for Cairo climate [18]. They concluded that this combination of tools is a very satisfactory and reliable simulation package for investigating sustainability and thermal performance analyses. Similarly, this paper investigation through DB-E+ modeling and simulation testing was carried out in summer during the calendar year 2016, excluding August, which is the school annual vacation. 


\subsubsection{Climatic features and weather data file of greater Cairo region}

The Egyptian Typical Meteorological Year (ETMY), the International Weather for Energy Calculations (IWEC) and Köppen classified Cairo climate as a hot semi-arid climate with a hot to extremely hot dry summer and mild to warm wet winter [14]. According to the reports published by the EMA (Egyptian Meteorological Authority), precipitation in Greater Cairo Region is $0.00 \mathrm{~mm} /$ day in summer and $0.20-0.50 \mathrm{~mm} / \mathrm{day}$ in winter. Also reports recorded $40.0-45.0^{\circ} \mathrm{C}$ as the maximum temperature range in summer, $20.0-25.0^{\circ} \mathrm{C}$ as a maximum temperature range in winter, $20.0-25.0^{\circ} \mathrm{C}$ as a minimum temperature range in summer, and $5.0-10.0^{\circ} \mathrm{C}$ as a minimum temperature range in winter.

$\mathrm{E}+$ Weather data file represents the typical long-term weather patterns of the intended region. The weather data file (for the year 2009) used for this study is (EGY_AL QAHIRAH_CAIRO INTL AIRPORT_ETMY.epw); this file is an EnergyPlus weather file with the summary statistics report (EGY_ALQAHIRAH_CAIRO INTL_AIRPORT_ETMY.stat) [15].

\subsubsection{Base case modeling}

Modeling and Analyses was performed for the same selected classroom, at which previous measurements had been performed. Fig. 8 shows the school building model with exactly the same construction and finishing materials. It also shows the case study location from the southern elevation view. Fig. 9 presents the school visualization model made by Design Builder software showing the sun path diagram at $13: 00 \mathrm{pm}$, on the $22^{\text {nd }}$ of June 2016. It presents a high rate of solar radiations onto the southern elevation at the mid of the school day time.
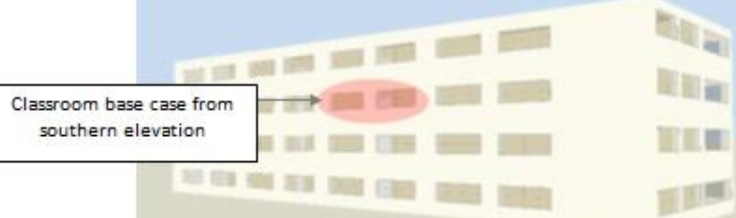

Fig. 8. School Model South elevation (left hand side) North elevation

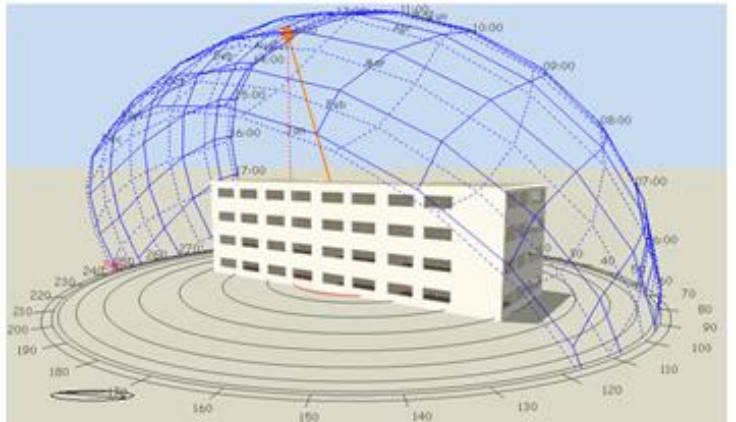

Fig. 9. School visualization model made by Design Builder software showing sun path diagram at 13:00, 22th June.

\subsubsection{Input parameters and materials thermal properties}

For efficient modeling and simulation of the school building, one should consider the existing construction materials and real parameters of the building to be applied to the computer modeling. As the thermo-physical properties of wall materials can affect the building's energy performance [7]. The Simulation input parameters and limitations based on the onsite data collected are shown in details in Table 1. It is assumed that the materials properties are constant during the simulation time. Table 2 considers the various layers in the 
Hala Hammad et al., Investigating the thermal comfort conditions in an existing school building......

building envelope starting from the outermost layer to the innermost layer, with their thermophysical properties.

Table 1.

Simulation input parameters in Design Builder E+ tool

\begin{tabular}{|c|c|}
\hline Element & Data \\
\hline Space dimensions & 8.00 length $\times 4.80$ width $\times 2.90$ height \\
\hline $\begin{array}{l}\text { Openings } \\
\text { orientation }\end{array}$ & two openings South orientation and a door on northern elevation \\
\hline $\begin{array}{l}\text { Openings } \\
\text { percentage }\end{array}$ & $40 \%$ \\
\hline Opening dimensions & 2.80 length $\times 1.30$ height \\
\hline Internal blinds & Non \\
\hline External shading & Non \\
\hline Lighting & 18 fluorescent lamps with a standard intensity of 450 lux \\
\hline Classroom capacity & 24 desks \\
\hline Occupancy pattern & $\begin{array}{l}\text { - } 1.12 \text { person } / \mathrm{m}^{2} \text { in normal school days } \\
\text { - For June and July, in summer courses, occupancy rate is about } 0.5 \text { person } / \mathrm{m}^{2} \\
\text { - Considering the one day-simulation } 22^{\text {nd }} \text { of June: the real occupancy } \\
\text { pattern was } 0.35 \text { person } / \mathrm{m}^{2}\end{array}$ \\
\hline Working time & $\begin{array}{l}\text { - Sunday to Thursday day, between } 8: 30 \text { am until } 2: 30 \mathrm{pm} \\
\text { - For June and July, in summer courses, the school days is from 9:00am until 12:30pm } \\
\text { - For the one day- simulation } 22^{\text {nd }} \text { of June, the school day started from } \\
\text { 9:00am until 12:30pm }\end{array}$ \\
\hline Annual vacation & August \\
\hline Metabolic rate & 0.75 \\
\hline Clothing & 0.3 clo. \\
\hline Holidays & 2 days / week \\
\hline HVAC template & No active cooling systems \\
\hline Natural ventilation & through opening \\
\hline
\end{tabular}

Table 2.

Existing construction materials thermal properties in Design Builder E+

\begin{tabular}{|c|c|c|c|c|c|c|c|}
\hline \multirow[t]{2}{*}{ Element } & \multirow[t]{2}{*}{ Materials } & \multirow{2}{*}{$\begin{array}{l}\text { Width } \\
(\mathrm{cm})\end{array}$} & \multicolumn{3}{|c|}{ Materials properties } & \multirow[t]{2}{*}{$\begin{array}{c}\text { U-Value } \\
\text { (W/m2-K) }\end{array}$} & \multirow{2}{*}{$\begin{array}{c}\text { Internal } \\
\text { heat } \\
\text { capacity } \\
(\mathrm{kj} / \mathrm{m} 2-\mathrm{k})\end{array}$} \\
\hline & & & $\begin{array}{c}\text { Conductivity } \\
\mathrm{W} / \mathrm{m}^{2}-\mathrm{k}\end{array}$ & $\begin{array}{c}\text { Specific heat } \\
\text { capacity } \\
\text { j/kg-k }\end{array}$ & $\begin{array}{c}\text { Density } \\
\mathrm{kg} / \mathrm{m}^{2}\end{array}$ & & \\
\hline \multirow{3}{*}{ Roof } & Al. deck & 2.0 & 45.2 & 500 & 7824 & \multirow{3}{*}{3.84} & \multirow{3}{*}{93.2} \\
\hline & Foam slag & 5.0 & 0.25 & 960 & 1040 & & \\
\hline & Al. deck & 2.0 & 45.2 & 500 & 7824 & & \\
\hline \multirow{3}{*}{$\begin{array}{l}\text { External } \\
\text { walls }\end{array}$} & $\begin{array}{c}\text { Cement } \\
\text { mortar and } \\
\text { plaster }\end{array}$ & 2.0 & 0.35 & 840 & 950 & \multirow{3}{*}{1.619} & \multirow{3}{*}{144.9} \\
\hline & Red brick & 24.0 & 0.85 & 840 & 1500 & & \\
\hline & $\begin{array}{l}\text { Cement } \\
\text { mortar and } \\
\text { plaster }\end{array}$ & 2.0 & & & & & \\
\hline
\end{tabular}


JES, Assiut University, Faculty of Engineering, Vol. 45, No. 3, May 2017, pp.344-359

\begin{tabular}{|c|c|c|c|c|c|c|c|}
\hline \multirow[t]{2}{*}{ Element } & \multirow[t]{2}{*}{ Materials } & \multirow{2}{*}{$\begin{array}{l}\text { Width } \\
(\mathrm{cm})\end{array}$} & \multicolumn{3}{|c|}{ Materials properties } & \multirow[t]{2}{*}{$\begin{array}{l}\text { U-Value } \\
\text { (W/m2-K) }\end{array}$} & \multirow{2}{*}{$\begin{array}{l}\text { Internal } \\
\text { heat } \\
\text { capacity } \\
\text { (kj/m2-k) }\end{array}$} \\
\hline & & & $\begin{array}{l}\text { Conductivity } \\
\mathrm{W} / \mathrm{m}^{2}-\mathrm{k}\end{array}$ & $\begin{array}{l}\text { Specific } \\
\text { heat } \\
\text { capacity } \\
\mathrm{j} / \mathrm{kg}-\mathrm{k}\end{array}$ & $\begin{array}{c}\text { Density } \\
\mathrm{kg} / \mathrm{m}^{2}\end{array}$ & & \\
\hline \multirow{3}{*}{$\begin{array}{c}\text { Internal } \\
\text { partitions }\end{array}$} & $\begin{array}{c}\text { Cement } \\
\text { mortar and } \\
\text { plaster }\end{array}$ & 2.0 & 0.35 & 840 & 950 & \multirow{3}{*}{2.55} & \multirow{3}{*}{158.8} \\
\hline & Red brick & 12.0 & 0.85 & 840 & 1500 & & \\
\hline & $\begin{array}{c}\text { Cement } \\
\text { mortar and } \\
\text { plaster }\end{array}$ & 2.0 & 0.72 & 840 & 1760 & & \\
\hline \multirow{4}{*}{ Floor } & Marble tiles & 2.00 & 3.5 & 1000 & 2800 & \multirow{4}{*}{2.49} & \multirow{4}{*}{216.24} \\
\hline & $\begin{array}{l}\text { Cement } \\
\text { mortar }\end{array}$ & 2.00 & 0.72 & 920 & 1650 & & \\
\hline & Sand & $\sim 6.00$ & 2.00 & 1045 & 1950 & & \\
\hline & $\begin{array}{l}\text { Reinforced } \\
\text { concrete }\end{array}$ & 15.00 & 2.5 & 1000 & 2400 & & \\
\hline \multirow{6}{*}{$\begin{array}{l}\text { Ground } \\
\text { Floor }\end{array}$} & Marble tiles & 3.00 & 3.5 & 1000 & 2800 & \multirow{6}{*}{1.113} & \multirow{6}{*}{194.8} \\
\hline & $\begin{array}{c}\text { Cement } \\
\text { mortar }\end{array}$ & 2.00 & 0.72 & 920 & 1650 & & \\
\hline & sand & $\sim 6.00$ & 2.00 & 1045 & 1950 & & \\
\hline & Cast concrete & 10.00 & 1.13 & 1000 & 2000 & & \\
\hline & $\begin{array}{c}\text { Insulting } \\
\text { material }\end{array}$ & 2.00 & 0.04 & 1400 & 15 & & \\
\hline & Rammed soil & & 1.2 & 880 & 1460 & & \\
\hline \multirow[t]{2}{*}{ Ceiling } & $\begin{array}{l}\text { Cement } \\
\text { Plaster }\end{array}$ & 2.00 & 0.35 & 840 & 950 & \multirow[t]{2}{*}{2.49} & \\
\hline & $\begin{array}{c}\text { Reinforced } \\
\text { concrete }\end{array}$ & 15.00 & 2.5 & 1000 & 2400 & & \\
\hline Door & $\begin{array}{l}\text { Painted } \\
\text { Wooden }\end{array}$ & 4.00 & & & & 3.00 & \\
\hline \multirow{2}{*}{$\begin{array}{c}\text { Windows } \\
\text { glazing }\end{array}$} & $\begin{array}{c}\text { Single } \\
\text { glazing }\end{array}$ & 0.6 & & & & \multirow[t]{2}{*}{5.77} & \\
\hline & $\begin{array}{l}\text { Aluminum } \\
\text { framing }\end{array}$ & 6.00 & & & & & \\
\hline
\end{tabular}

\section{Results and discussion}

\subsection{Comparison between simulation results and monitored data}

Real measurements for the temperatures and humidity, which are collected from the case study classroom in $22^{\text {nd }}$ of June, are compared to the simulation results as seen in Fig. 10 and Fig. 11. The computer model was built as close as possible to the real case including construction materials, glazing, and shading. The base case takes into account the same parameters of "day-simulation", shown in Table 1, i.e., the internal gains from solar radiations (incidence through windows), lighting and occupancy level. 
As mentioned before, Energy Plus simulation tool has been validated by many researches and specially in Cairo region [10]; nevertheless, this comparison is carried on only to ensure its effectiveness in this case study. Fig. 10 and Fig. 11 show that the simulation results, for the same day of investigations, reached near levels to the monitored data. However, there is a slightly deviation of the simulation results from the measurement data.

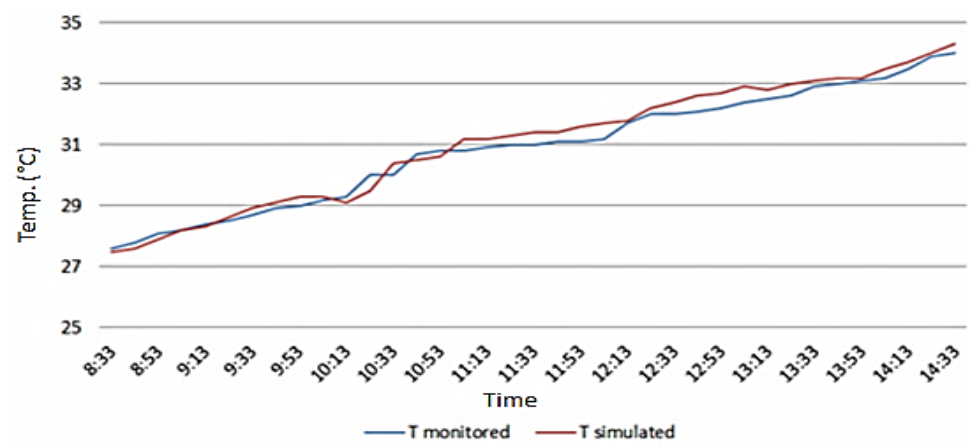

Fig. 10. "day- simulation": Simulated indoor space temperature versus monitored data for a summer school day $22^{\text {nd }}$ of June

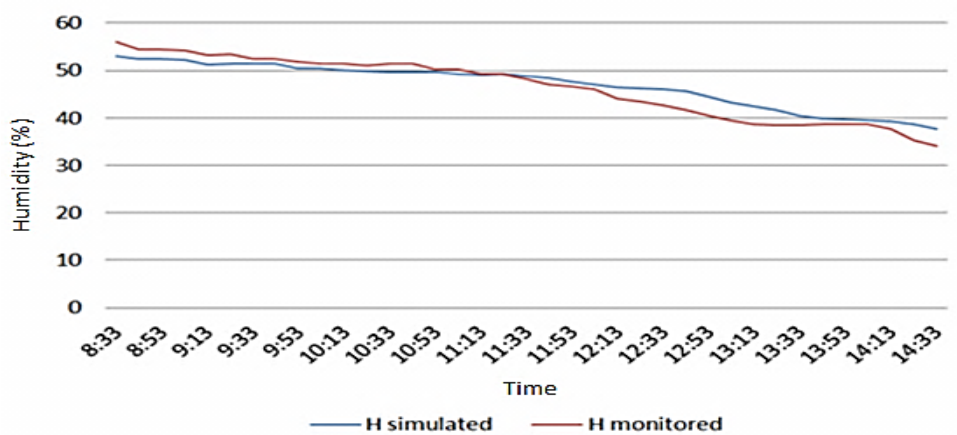

Fig. 11. "day- simulation": Simulated internal humidity versus monitored data for a summer school day $22^{\text {nd }}$ of June

According to Rahman et al. (2008), it has been shown that if the difference between measured readings and simulation results is less than $5 \%$ then the modeling procedure can be described as a valid one[2]. Hence, for this case study, the validation error is calculated to be approximately $4.37 \%$, which is less than the validity range. This encourages the authors to guarantee the simulation tool effectiveness when used in the classroom annual investigations, the main concern of this paper.

\subsection{Annual thermal comfort simulation results}

The authors concern the annual thermal comfort investigations as the main objective of this paper in order to estimate the space thermal performance throughout an academic year. The input simulation parameters are being fixed and based on real annual aspects. Results concerns: annual mean indoor air temperature, average annual predictive mean vote model, annual discomfort hours, and average annual internal heat balance. From the annual simulation results and the data conducted, which are explained in the next sections, one can predict the annual cooling loads needed for the building.

\subsubsection{Annual mean indoor air temperature}

Energy Plus simulation results, in Fig. 12, present the annual mean indoor air temperature of the classroom base case study. This indoor air temperature affects directly the students' 
thermal comfort. According to ASHRAE Standard 55 [6], Adaptive Comfort Standard (ACS) in this case is calculated to be in the range of $23.5-28^{\circ} \mathrm{C}$. It is shown in the same figure that about $45 \%$ of the annual temperature values are above $28^{\circ} \mathrm{C}$, which is considered the upper limit of the comfort range. Moreover, around $30 \%$ of the annual temperatures are below $23.5^{\circ} \mathrm{C}$, which is considered the lower limit of thermal comfort range during winter.

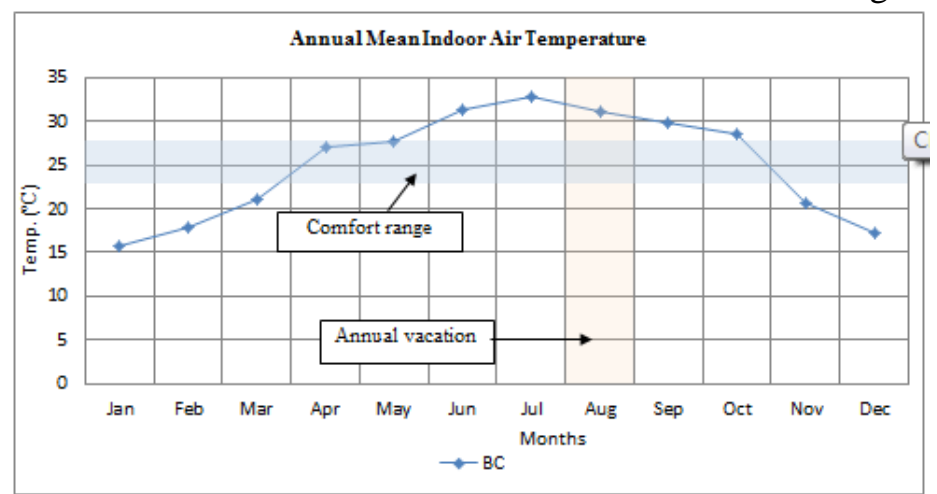

Fig. 12. Annual mean air temperatures for the base case

\subsubsection{Annual predicted mean vote model}

Predicted Mean Vote model (PMV) is one of the most recognized thermal comfort models, it is originally introduced by Fanger, ISO 7730 and ASHRAE 55 standards [8]. The PMV is an index that predicts the mean value of the votes of a large group of persons on the 7-point thermal sensation scale, based on the heat balance of the human body. According to ASHRAE 55 standards, the acceptable thermal comfort range for a PMV lies between -1 and +1 . Average annual PMV was calculated for the classroom case study using E+ depending on the parameters of metabolic rate, occupancy rate, and clothing, in addition to the mean indoor air temperature and humidity (which were estimated from E+ simulations). Figure 13 predicts the average monthly PMV during a complete academic year for the classroom case study.

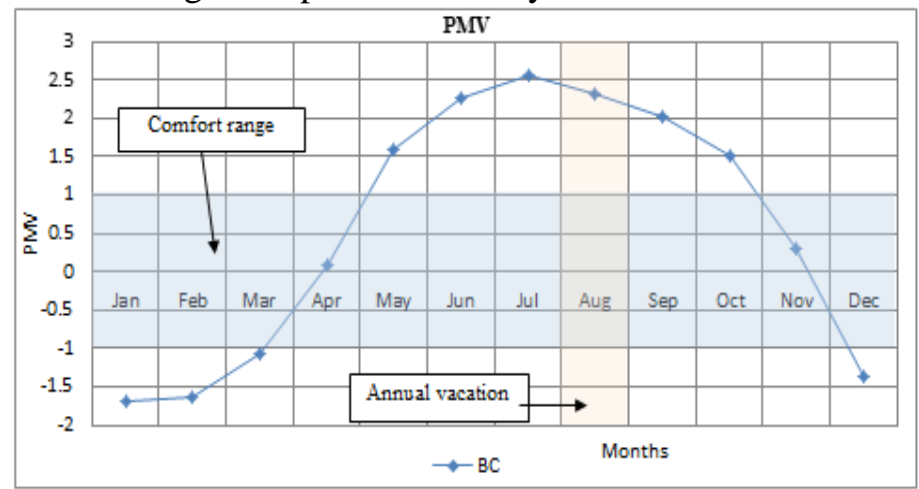

Fig. 13. Annual indoor PMV in classroom base case results

Annual PMV results in the Fig. 13 show that the maximum PMV estimated in summer reaches a maximum discomfort of +2.5 in July, whilst the minimum PMV is estimated in winter to be -1.7 . The average PMV during the summer months is about +1.8 which indicates a high level of thermal discomfort in the classroom. PMV comfort level ranges of $-1 \leqq$ PMV $\leqq 1$ reaches in almost $35 \%$ of the total hours during the year. Hence, the classroom space on average are estimated to be thermally discomfort for about $65 \%$ of the year which is considered a very high percent. 


\subsubsection{Annual discomfort hours}

Energy Plus tool can predict the annual working hours distribution analysis for the classroom case study. Figure 14 shows that there are annually about 3200 hours in which the classroom temperature is at or above the $26^{\circ} \mathrm{C}$, where as it is including about 2600 hours annually with a temperature at or above the $32^{\circ} \mathrm{C}$. The most important index in these values is that there are annually about 3100 hours in which the temperature is equal to or above the temperature $28^{\circ} \mathrm{C}$ which is the maximum comfort range. This means that there are about 3100 hours exceeding the comfort level in summer months including the annual vacation. By subtracting August month hours (as it is considered the annual vacation) from the investigations, one will figure out that the number of hours more than the comfort temperature level, i.e., the $28^{\circ} \mathrm{C}$, are about 2765 hours throughout a whole academic year. As a conclusion, the number of the annual discomfort hours presents about $35 \%$ of whole academic year hours and about $76 \%$ of the total summer school days hours. This percentage is considered to be very high ratio of the year, which leads us to think about solutions that can be included in the future, buildings in order to decrease the number of annually discomfort hours.

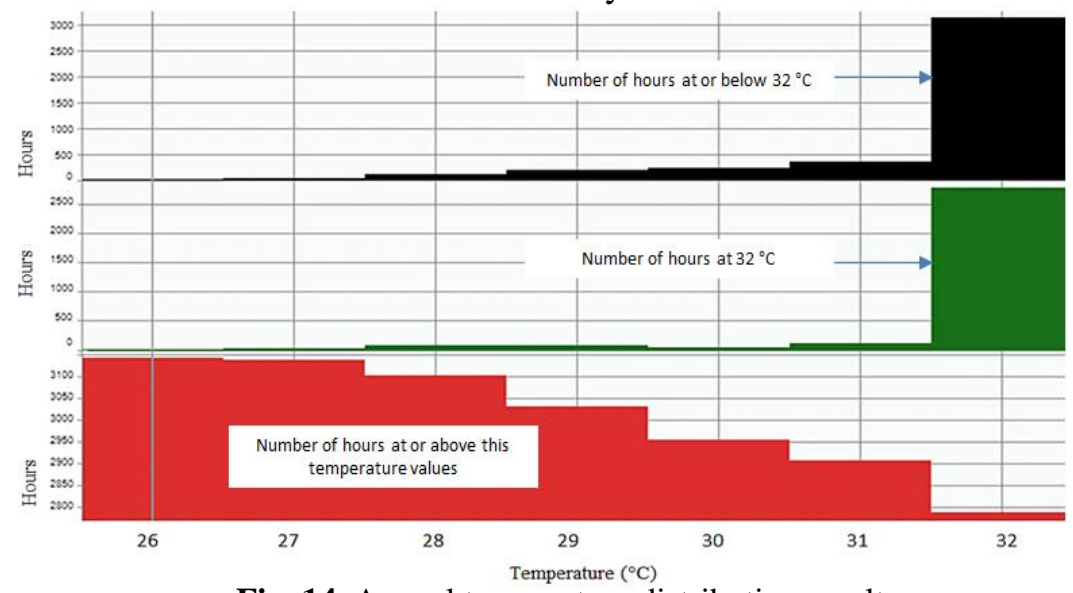

Fig. 14. Annual temperature distribution results

\subsubsection{Annual internal heat gain balance}

Heat gained into the space is resulting from three sources: heat radiated from the occupants bodies, heat conducted from the external fabrics through glazing and walls, and through direct solar energy entering the space through window openings. While, the heat lost due to its absorption by thermal mass or by convection through using alternative cooling systems. The positive values indicate an increasing in space heat gains and therefore increase in cooling loads, while the negative values present the loss of internal heat and; therefore, the reduction of cooling loads. Figure 15 presents the annual hourly heat gain and loss in the classroom case study through fabric and occupants. Where June and July are having less occupants than the rest of the year, as they are considered in the summer school days in which the occupants level is minimized to $50 \%$ and school hours is until 12:30 pm, and August is the annual vacation.

Thermal balance is obtained when the internal heat production in the space is equal to the heat loss from the space. In this classroom case study, Fig. 15 indicates an extreme increase in the internal heat gain through exterior windows and occupants throughout the academic year. It shows also that the walls thermal mass absorbs a small percentage of the internal heat gain. The average annual internal heat gain balance is about $261.6 \mathrm{~kW} / \mathrm{m}^{2}$. 
This high level of annual internal heat gain will result in high need of annual cooling loads. Results indicate the importance of introducing alternative glazing materials in order to block solar radiations. Additionally, it needs new construction composites to absorb excess internal heat gain. Finally, the results show the necessity of having new passive and/or active cooling systems in order to achieve thermal balance in the future buildings.

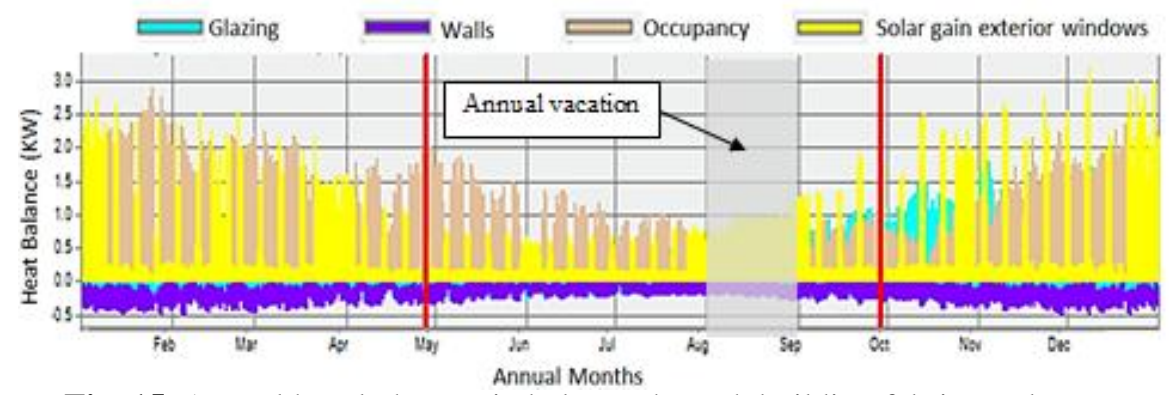

Fig. 15. Annual hourly heat gain balance through building fabrics and occupants

\section{Conclusion and recommendations}

This paper investigates the thermal comfort conditions for an existing naturally ventilated public primary school in Nasr city region in Cairo governorate in Egypt. A classroom in the second floor is selected to be as a base case study for all the investigations carried in this paper. Measuring and recording of the classroom air temperature and humidity all over a summer school day from 8:30 am until 02:30 pm, using Elitech tempreture-humidity data logger (model URC-4HC), has been presented. The outputs of measurements indicate a high level of thermal discomfort within the primary public school classrooms in the typical summer day, in which the measurements were recorded. The main contribution of this paper concerns modeling and numerically simulating the thermal performance of the classroom case study by Design Builder modeling with Energy Plus simulation tool. Annual thermal performance simulations are done for the case study in order to predict the yearly average indoor air temperature, average annual Predicted Mean Vote (PMV) model, annual number of discomfort hours, and annual heat balance. The main achievements of this study are as follows:

- The acceptability ratio of thermal comfort calculated by (ACS) model ranges from $23.5^{\circ} \mathrm{C}$ to $28^{\circ} \mathrm{C}$. In this case, it has been found that $45 \%$ of the mean indoor temperatures are more than the comfort range limit throughout the academic year.

- The average PMV across the classrooms is +1.8 in summer months, which indicate a high level of thermal discomfort.

- Annual discomfort hours (more than $28^{\circ} \mathrm{C}$ ) are about 2765 hours, which is about $35 \%$ of the total hours throughout the whole academic year (excluding the annual summer vacation).

- The average annual internal heat gain balance is about $261.6 \mathrm{kWh} / \mathrm{m}^{2}$, which means a high level of cooling loads.

Therefore, the annual simulation results indicate a high level of thermal discomfort and high annual cooling loads. These findings indicate the importance of integrating passive cooling alternative strategies or energy efficient cooling systems into the classroom case study in order to achieve the students' thermal comfort. Recommended passive and active strategies could be for further researches concerning: 


\section{Passive alternative strategies:}

- Designing the school building according to environmental principals, e.g., considering the building form, orientation, use of thick or double walls, high ceilings, green roofs and facades, opening percentage, skylights, shadings, courtyards, wind catchers, etc.

- Using advanced glazing materials, e.g., low e-glazing, smart windows, electrochromic glazing, etc.

- Using alternative construction materials composites for building fabrics, e.g., renewable composites, Nano materials, earth composites, etc.

- Integrating the internal spaces with phase change materials or boards in order to stabilize the indoor mean air temperature.

\section{Efficient active strategies:}

- Integrating energy efficient cooling systems, e.g., solar air conditioning, geothermal cooling systems, chilled ceilings, etc.

- Integrating active thermal storage systems that take the benefits of thermal mass and the energy efficient cooling systems.

This research may assist designers to improve schools thermal performance trying to achieve the students' thermal comfort all over the academic year in future school buildings in Cairo, Egypt.

\section{REFERENCES}

[1] Haddad S., King S., Osmond P., "Enhancing thermal comfort in school buildings", 10th International Healthy Buildings Conference, At Brisbane, Volume: Proceedings, Healthy Buildings, 2012.

[2] Rahman, M.M., Rasul, M.G. Khan, M.M.K., "Energy conservation measures in an institutional building by dynamic simulation using DesignBuilder". In: Third International Conference on Energy and Environment, Cambridge, 23-25 February, 2008.

[3] Sayed A., Abdallaha H., "Analysis of Thermal Comfort and Energy Consumption in Long Time Large Educational Halls (Studios), Assiut University, Egypt, 9th International Symposium on Heating", Ventilation and Air Conditioning (ISHVAC) and the $3^{\text {rd }}$ International Conference on Building Energy and Environment (COBEE), Procedia Engineering 121, $1674-1681,2015$.

[4] Jones L. and Wilde P., "A case study into the relation between tempreture and work productivity in offices in the UK, $27^{\text {th }}$ conference on passive and low energy architecture", louvain-la-Neuve, Belgium, 13-15, 2011

[5] Zahiri S., Sharples S., Altan H., "Developing sustainable school design in Iran, a thermal comfort survey of a secondary school in Tehran, school of architecture", university of Sheffield, UK, 2014.

[6] Brager G.S. and de Dear R., Climate, Comfort, \& Natural Ventilation: A new adaptive comfort standard for ASHRAE Standard 55, Center for Environmental Design Research Center for the Built Environment (University of California, Berkeley), 2001.

[7] Long L. and Ye H., "Effects of thermophysical properties of wall materials on energy performance in an active building", The 7th International Conference on Applied Energy ICAE2015, Energy Procedia 75, 2015.

[8] Volkov A. 2014, Artem V., Pavel D., "Modelling the Thermal Comfort of Internal Building Spaces in Social Buildings", Theoretical Foundation of Civil Engineering (23RSP) (TFoCE 2014) Energy Procedia 362 - 367, 2014. 
[9] K.M. Dewidar, A.H. Mahmoud, Moussa, "Enhancing the human thermal comfort in-side educational buildings in hot arid regions", International conference of global cli-mate change, biodiversity and sustainability, challenges and opportunities, AAST Egypt, 2013.

[10] Gado T, Mohamed M. "Assessment of thermal comfort inside primary governmental classrooms in hot-dry climates Part I-a case study from Egypt", Second Int. Conf. Whole Life Urban Sustain. Its Assess., Loughborough, UK: 2009.

[11] Mohamed M, Gado T. "Assessment of thermal comfort inside primary governmental classrooms in hot dry climates Part II: A case study from Egypt", Loughborough, UK: Loughborough University, pp. 991 - 1001. 2009.

[12] Farghal AAF. Studying the adaptive comfort model: a case study in Arid climate: Cairo, Egypt. Karlsruher Inst. für Technologie, Diss., 2011.

[13] Gado, T., M. Mohamed and S. Unwin,. "The environmental performance of classrooms in Egypt: a case study from El-Minya governorate", The Second Scottish Conference for Postgraduate Researchers of the Built \& Natural Environment, Glasgow Caledonian University, pp.643-651, 2005.

[14] Ahmed Saleem, Ali Abel-Rahman, Ahmed Hamza Ali, Shinichi Ookawara, "Experimental Study on Thermal Comfort Conditions in Existing Public Primary Schools Buildings in Upper Egypt", International Conference on Sustainability in Energy and Buildings- SEB-14, Cardiff, Wales, UK, 2014.

[15] DesignBuilder Software, http://www.designbuilder.co.uk/, 2016.

[16] Elitechs data loggerhttp://www.elitechus.com/temperature_logger/URC_4HC_150.html, 2016.

[17] EnergyPlus, http://apps1.eere.energy.gov/buildings/energyplus/, 2016.

[18] Sheta W. and Sharples S., "A Building Simulation Sustainability Analysis to assess Dwellings in a New Cairo Development", Fourth National Conference of IBPSA-USA New York City, New York August $11-13,2010$ 
Hala Hammad et al., Investigating the thermal comfort conditions in an existing school building...... استقصاء ظروف الراحة الحرارية في المباني المدرسية القائمة في مصر

\section{ملخص}

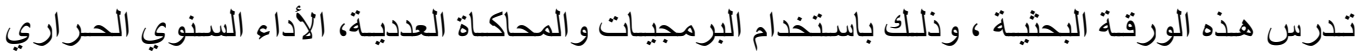

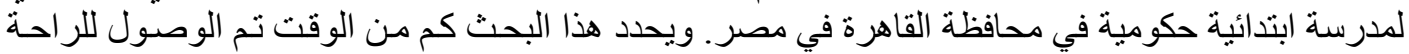

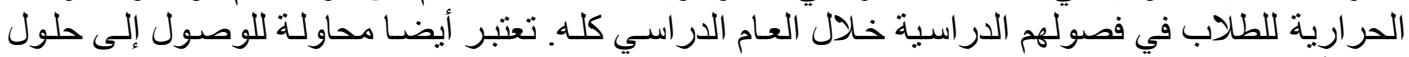

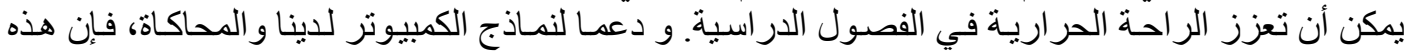

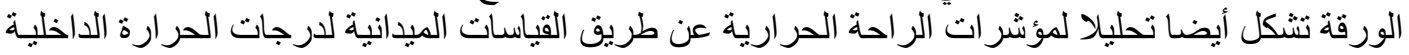

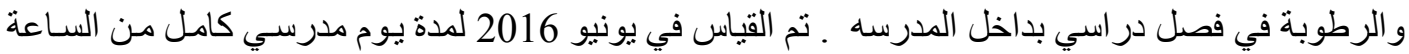

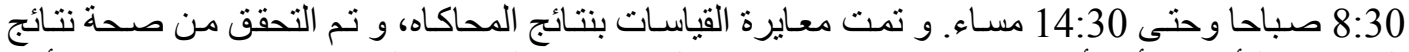
المحاكاة و التأكد من أنها أداة موثوق بها مما نتج عنه فاعلية برنـامج المحاكاه للإسـتخدام في استقصـاء الأداء

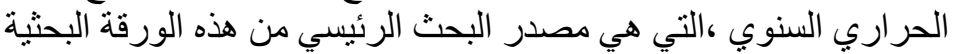

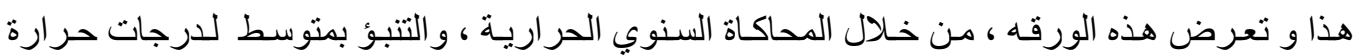

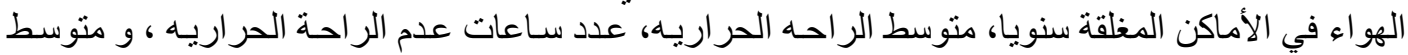

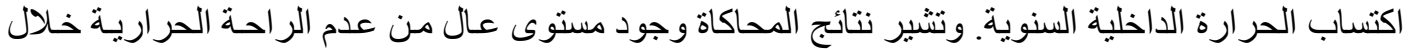

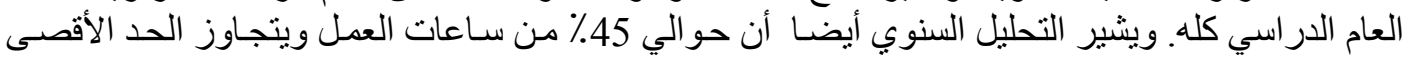

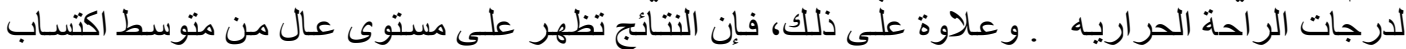

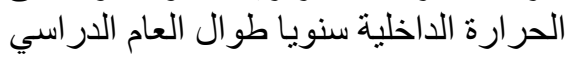

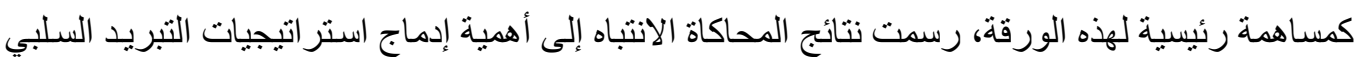

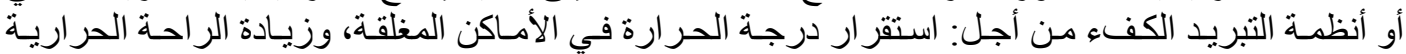

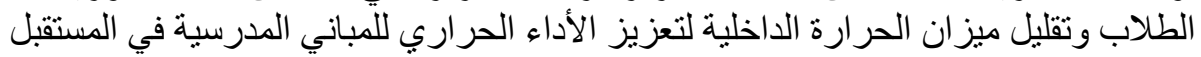

